\title{
FIQIH HAM DAN HAK KEBEBASAN BERIBADAH MINORITAS DZIMMI DI INDONESIA
}

\author{
M. Alifudin Ikhsan \\ Program StudiMagister Pendidikan Pancasila dan Kewarganegaraan Universitas Negeri Malang \\ Jl. Semarang No.5 Malang \\ email: um.alifudin93@gmail.com
}

\begin{abstract}
Indonesia is a multicultural country. There are various religions, tribes, cultures and customs. This diversity is a necessity that must be lived as a force in building the country. However, the diversity is tested by various discriminatory events. One is the freedom to worship religious minorities in the midst of a particular religion. The establishment of places by minority religions in various regions continues to reap the controversy. Maturity of the thinking of the majority becomes an important part in realizing the balance of social relations. Therefore, this article tries to realize a new idea of Fiqh HAM. The results of the Qur' anic conception are poured in the idea of human rights fiqh that seeks to build equal rights of worship for citizens. Fiqh HAM is expected to create public awareness to respect and respect the activities of minority worship.
\end{abstract}

Key Words: fiqh, human right, worship, minority

\begin{abstract}
Indonesia merupakan negara multikultural. Terdapat berbagai agama, suku, budaya dan adat istiadat. Keberagaman ini merupakan sebuah keniscayaan yang harus dijalani sebagai kekuatan dalam membangun negara. Namun, keberagaman itu seolah diuji dengan berbagai peristiwa diskriminasi. Salah satunya adalah kebebasan beribadah kaum minoritas agama di tengah mayoritas suatu agama tertentu. Pendirian rumah ibadah oleh agama-agama minoritas di berbagai daerah terus menuai kontroversi. Pendewasaan pemikiran umat mayoritas menjadi bagian penting dalam mewujudkan keseimbangan hubungan sosial. Oleh karena itu, Artikel ini mencoba untuk mewujudkan gagasan baru mengenai Fikih HAM. Hasil konsepsi Al-Quran tersebut dituangkan dalam gagasan fiqih HAM yang berupaya untuk membangun kesetaraan hak beribadah bagi warga negara. Fiqh HAM diharapkan mampu membentuk kesadaran masyarakat untuk menghargai dan menghormati aktivitas peribadatan kaum minoritas.
\end{abstract}

Kata Kunci: fiqih, hak asasi manusia, ibadah, minoritas

Isu pendirian rumah ibadah bagi kaum minoritas, baik minoritas berbeda agama dan keyakinan atau minoritas sekte kelompok keagamaan, terus menjadi permasalahan yang serius. Fenomena ini menimbulkan kompleksitas berbagai aspek kehidupan, mulai dari agama, hukum, adat, budaya, keyakinan, tata masyarakat, kultur sosial, dan politik. Ironisnya, permasalahan ini semakin meningkat sejak pertengahan abad ke-20. Laporan pertanggungjawaban Kementerian Agama (2015) merilis 47 fakta kasus kekerasan atas nama agama yang terjadi dalam kurun waktu 10 tahun terakhir. Kondisi tersebut $87 \%$ terjadi karena permasalahan sosial berkaitan dengan pendirian rumah ibadah kelompok agama tertentu. Konflik permasalahan peribadatan ini muncul karena adanya sikap membangga-banggakan kelompok atau golongan yang tidak diposisikan sebagaimana mestinya (Taufiqurrahman, 2013).

Upaya menghalangi pendirian tempat peribadatan suatu agama dengan tujuan sentimen golongan, tentu tidak dapat dibenarkan. Pada hakikatnya, kebebasan memeluk agama dan keyakinan serta menjalankan peribadatannya merupakan hak asasi setiap manusia yang dilindungi oleh konstitusi, termasuk warga minoritas dzimmi (warga non muslim yang tunduk kepada aturan pemerintahan muslim serta tidak memerangi atau membahayakan umat muslim yang mayoritas didaerah tersebut).Fakta dari 
berbagai konflik keagamaan yang melibatkan tempat peribadatan di Indonesia menunjukkan bahwa aksi ini lebih dilatar-belakangi oleh status bangunan yang ilegal, indikasi aliran sesat dan kesalahpahaman antarjemaat (Kumelo, 2015). Awalnya, perusakan ini bertujuan untuk menegakkan hukum (tertib bangunan), mengusir, dan/atau mematikan aktivitas aliran sesat tersebut. Namun kenyataannya justru menimbulkan dampak intoleran.

Pemerintah sebagai pemegang kekuasaan telah mengeluarkan peraturan bersama Menteri Agama dan Menteri Dalam Negeri Nomor 8 \& 9 Tahun 2006 tentang pedoman pemberdayaan forum kerukunan umat beragama dan pendirian rumah ibadat. Peraturan ini dikeluarkan sebagai arah kebijakan pemerintah dalam pembangunan nasional dibidang agama. Ironisnya, peraturan yang sejatinya memberi rasa keadilan bagi seluruh elemen masyarakat, justru terkesan membatasi aktivitas beribadah kaum minoritas dzimmi. Pasal 14 ayat (2) peraturan tersebut, menyaratkan suatu tempat peribadatan baru dapat didirikan setelah mendapat persetujuan sekurang-kurangnya 60 orang di sekitar lokasi, harus mendapatkan izin dari tokoh masyarakat dan kepala daerah di wilayah tersebut.

Kesan pembatasan kegiatan peribadatan di atas, muncul dengan asumsi agar tidak terjadi lagi penolakan terhadap pendirian suatu rumah ibadah. Hal ini justru menjadikan peraturan ini cacat nilai dan norma, dimana masyarakat Indonesia mempunyai kultur sosial pluralis multikultural yang sulit terekam aktivitasnya (Al-Hakim, 2016). Permasalahan konflik pendirian rumah ibadah akan sering terjadi karena tingkat sensitifitas permasalahan yang kompleks. Apabila kedewasaan masyarakat belum terbangun dengan kokoh, tentu hal ini akan menjadi potensi disintegrasi bangsa (Wiyono, 2015).

Tulisan ini lahir sebagai ikhtiar untuk mendewasakan masyarakat melalui kajian fiqih HAM (hak asasi manusia) yang digali dari universal values nilai-nilai Al-Quran, hadis, ijtihad para ulama' dan kajian keislaman lainnya. Paparan problematika pendirian rumah ibadah sebagai realita kehidupan akan dikaji dalam perspektif AlQuran terhadap hak beribadah kaum dzimmi. Hasil konsepsi Al-Quran tersebut dituangkan dalam gagasan fiqih HAM yang berupaya untuk membangun kesetaraan hak beribadah bagi warga negara. Fiqh HAM diharapkan mampu membentuk kesadaran masyarakat untuk menghargai dan menghormati aktivitas peribadatan minoritas dzimmi, mengurangi retensi kekerasan antarumat beragama, menciptakan kehidupan yang harmonis berdasarkan prinsip-prinsip syariat Islam (maqasid al-syariah).

\section{PROBLEMATIKA PENDIRIAN RUMAH IBADAH MINORITAS DZIMMI}

Isu terbaru terkait konflik horizontal berkaitan dengan minoritas dzimmiadalah kasus penodaan agama oleh Gubernur DKI Jakarta Basuki Tjahaya Purmana. Kasus ini mengundang reaksi sebagian besar umat Islam Indonesia dengan segala bentuk argumen yang disampaikan. Kasus ini mengakibatkan pengelompokan dan marjinalisasi kelompok masyarakat tertentu. Hal ini menunjukkan bahwa sensitivitas permasalahan agama di Indonesia sangat tinggi. Disisi yang lain, ketika belum hilang ingatan masyarakat atas peristiwa kerusuhan yang mengakibatkan sedikitnya satu orang tewas dan belasan luka-luka hingga pembakaran musholla di Tolikara Papua, masyarakat kembali disuguhkan dengan kerusuhan mengatasnamakan agama di Singkil Aceh.

Ironisnya, deretan kasus kerusuhan, penolakan hingga pembakaran dan perusakan rumah ibadat sering terjadi. Ancaman stabilitas hingga disintegrasi bangsa karena konflik horizontal rentan terjadi di Indonesia (Kemenag, 2015).Kondisi ini terjadi karena kemajemukan bangsa Indonesia. Padahal, keberagaman ini merupakan kekuatan dasar dalam membangun sebuah komunitas. Firman Allah dalam surat alHujurat ayat 13,

"Hai manusia, Sesungguhnya Kami menciptakan kamu dari seorang laki-laki dan seorang perempuan dan menjadikan kamu berbangsa-bangsa dan bersukusuku supaya kamu saling kenalmengenal. Sesungguhnya orang yang paling mulia diantara kamu disisi Allah ialah orang yang paling taqwa diantara kamu. Sesungguhnya Allah Maha mengetahui lagi Maha Mengenal".

Makna pluralitas dalam ayat diatas dimaknai oleh Quraish Shihab sebagai bentuk kemajemukan yang diberikan oleh Allah. Manusia diminta untuk menghormati dan menghargai perbedaan tersebut. Perbedaan ini bukan menjadi suatu kelemahan, namun justru menjadi kekuatan suatu kelompok 
masyarakat. Ayat inilah yang menjadi landasan betapa pentingnya menghormati dan menjunjung tinggi HAM ditinjau dari kesamaan derajat dan kedudukan di mata Allah SWT (Shihab, 2002).

Untuk mencegah dan meminimalisir potensi retensi konflik antarumat beragama di Indonesia, pemerintah telah mengeluarkan peraturan bersama Menteri Agama dan Menteri Dalam Negeri Nomor 8 \& 9 Tahun 2006 tentang pedoman pelaksanaan tugas kepala daerah/wakil kepala daerah dalam pemeliharaan kerukunan umat beragama, pemberdayaan forum kerukunan umat beragama dan pendirian rumah ibadat. Dengan adanya peraturan tersebut diharapkan potensi konflik di daerah dapat dikurangi. Namun, jika ditelaah lebih lanjut terkait dengan peraturan tersebut, terdapat beberapa hal yang justru berpotensi menimbulkan konflik baru di tengah masyarakat.

Salah satu potensi konflik yang ada dalam peraturan tersebut adalah kewajiban setiap agama yang akan mendirikan rumah ibadah harus mendapatkan persetujuan sekurang-kurangnya 60 orang sekitar, mendapatkan izin dari tokoh masyarakat dan kepala daerah dimana rumah ibadah itu didirikan. Hal ini akan sulit dipenuhi oleh agama minoritas dzimmi yang terkesan tidak diterima dilingkungannya. Mengapa demikian?, Bagi kaum minoritas dzimmi, mendapatkan pengakuan di tengah mayoritas muslim sangatlah sulit. Tekanan, intimidasi dan pandangan sinis akan selalu dilontarkan oleh kaum mayoritas agar kaum minoritas tersebut tidak mendirikan tempat ibadah di lingkungannya. Di sisi lain, mendapatkan persetujuan dari tokoh masyarakat dan kepala daerah juga cenderung dipersulit. Kondisi demikian mengakibatkan adanya ketidaksetaraan hak pendirian rumah ibadah bagi warga negara.

Fakta permasalahan di atas diantaranya adalah kasus perusakan Gereja Kristen Jawi Wetan di Ponorogo Jawa Timur tahun 2016 yang dilakukan oleh kelompok Front Pembela Islam (FPI) karena tudingan pendirian rumah ibadat tersebut tidak mempunyai izin. Kondisi serupa juga melatarbelakangi kejadian di Tolikara Papua dan Aceh Singkil. Fenomena kerusuhan atasnama agama ini menandai gagalnya penanaman nilai-nilai toleransi antarumat beragama. Padahal berbagai upaya telah dilakukan pemerintah untuk mencegah terjadinya konflik agama. Negara juga menempatkan hak peribadatan sebagai hak dasar yang wajib dijunjung tinggi oleh setiap warga negara.
Kebebasan umat beragama dalam beribadah juga telah menjadi kesepakatan dunia melalui International Covenan of Civil and Political Right (Konvensi internasional atas hak sipil dan politik) (Rodli, 2013:16). Konvensi internasional tersebut ditetapkan oleh PBB pada tahun 2006 yang telah di rativikasi oleh semua negara di dunia termasuk Indonesia. Menyoal kembali tentang peraturan bersama Menteri berkaitan dengan pendirian rumah ibadah di atas,cenderung bertentangan dengan Pasal 33 Undang-undang Dasar Negara Republik Indonesia Tahun 1945. Pada dasarnya, hak beragama adalah hak asasi manusia yang tidak dapat dikurangi atau dibatasi dalam keadaan apapun oleh siapapun juga. Terlebih setiap orang bebas memilih agama dan beribadat menurut agama dan kepercayaannya masingmasing.

\section{KONSEPSI AL-QURAN TENTANG HAK BERIBADAH MINORITAS DZIMMI}

Secara epistemologis, dzimmi berarti warga non-muslim yang menjadi warga negara Islam, tunduk dan patuh terhadap aturan Islam (Yunus, 1989, 135). Secara istilah, dzimmi adalah sekelompok orang non-muslim yang hidup (bertempat tinggal) di wilayah yang berada di bawah kekuasaan muslim (Jonathan, 1995:317). Maknadzimmi berbeda dengan harbi. Jika istilahharbiyakni orang non-muslim yang menentang dan memusuhi Islam. Dalam konteks ini, yang perlu ditegaskan adalah posisi Indonesia yang bukan sebagai negara agama. Indonesia adalah negara kesatuan yang berprinsip Pancasila, dengan mengedepankan persatuan dan kesatuan dalam membangun sebuah negara berdaulat. Indonesia tidak didirikan berdasarkan keyakinan agama tertentu, namun dibangun berdasarkan prinsip persatuan (Wiyono, 2015).

Menurut Sayyid Sabiq, dzimmijuga berbeda dengan kaum muahad. Muahad adalah warga non-muslim yang mengadakan perjanjian dengan orang Islam, baik perjanjian itu berisi memohon jaminan keamanan dari orang Islam atau perjanjian gencatan senjata yang ditetapkan oleh penguasa Islam, maupun berdasarkan kontrak fidyah(Wiyono, 2015:114). Selain itu, alMusta'min adalah warga non-muslimharbi yang memasuki negara Islam dengan aman. Jika ditinjau dari kondisi ini maka perbedaan agama di Indonesia dapat dikategorikan menjadi kaum dzimmi 
(warga non-muslim) yang harus dilindungi dan saling menghargai menuju kehidupan yang aman dan damai.

Konsep ahl al-dzimmah merupakan cikal bakal munculnya konsep penomorduaan terhadap non-muslim. Ahl al-dzimmah adalah komunitas non-muslim yang melakukan kesepakatan untuk hidup di bawah tanggungjawab dan jaminan kaum muslimin. Mereka mendapatkan perlindungan dan keamanan serta mendapatkan hak hidup dan bertempat tinggal di tengah mayoritas muslim (Huwaydi, 1999:112).Dalam kitab fikih klasik, ahl al-dzimmah dituntut melaksanakan kewajiban, tetapi tidak mendapatkan hak yang sejajar dan setara sebagaimana komunitas muslim lainnya. Atas pendapat inilah, kaum dzimmi disebut sebagai kaum nomor dua (Al-Zuhaili, 1426H).

Pemahaman sebagian besar orang dalam menyikapi fikih klasik tersebut masih bersifatetnosentrismeyang tidak menghargai dan menjunjung keserataan hak. Padahal Al-Quran menyerukan semangat untuk menghormati dan menghargai ahl al dzimmah. Al-Quran juga secara tegas memberikan keleluasaan mereka untuk beribadat sesuai dengan agama dan keyakinan masing-masing dalam Surat Al-An'am ayat 108 sebagai berikut,

"Dan janganlah kamu memaki sembahan-sembahan yang mereka sembah selain Allah, karena mereka nanti akan memaki Allah dengan melampaui batas tanpa pengetahuan. Demikianlah Kami jadikan Setiap umat menganggap baik pekerjaan mereka. kemudian kepada Tuhan merekalah kembali mereka, lalu Dia memberitakan kepada mereka apa yang dahulu mereka kerjakan".

Tafsir Al-Maraghi menyebutkan ayat di atas melarang umat manusia untuk memaki sesembahan agama lain, itu artinya tidak boleh menghina agama lain demi menghormati dan menghargai agama tersebut. Islam menempatkan akhlak sebagai bagian dari jati dirinya. Ayat diatas mengajarkan salah satu nilai toleransi dengan cara yang baik. Hal ini juga akan menumbuhkan jiwa cinta tanah air di masa sekarang (Al-Maraghi, 1976). Di ayat yang lain, toleransi dalam Islam juga telah diajarkan syarat dan tujuannya. Dijelaskan dalam tafsir Fathul al-BayanAllah tidak melarang kalian untuk menghormati dan berbuat baik kepada mereka (ahl al-dzimmah) semuanya, baik dengan perkataan maupun perbuatan. Senada dengan itu, Tafsir Al-Misbah menyebutkan bahwa ayat tersebut memerintahkan kita untuk bersikap tegas terhadap orang kafir. Namun, hal ini berlaku bagi mereka yang memusuhi atau memerangi umat Islam. Hal yang berbeda disebutkan dengan ayat ini adalah Allah tidak melarang kita untuk berbuat baik dan berlaku adil terhadap orang-orang yang tidak memerangi kita karena agamanya. Hal ini menunjukkan bahwa Islam sangat menghormati pendapat dan tradisi serta kebiasaan orang-orang kafir dengan syarat mereka tidak memusihi dan memerangi umat Islam (Shihab, 2002).

Ayat ini berkaitan dengan Asbab al-Nuzul nya yang dijelaskan oleh Shihab (2013) sebagai berikut:

“Asma' binti Abu Bakar menceritakan bahwa ibunya yang ketika itu masih dalam keadaan musyrikah berkunjung kepadanya, ia pergi menemui Rasul SAW dan bertanya: "Bolehkah saya menjalin hubungan baik dengan ibu saya?". Kemudian Nabi SAW menjawab "Ya, jalinlah hubungan baik dengannya" (H.R. Bukhari dan Muslim). Imam Ahmad meriwayatkan melalui Abdullah bin Zubair bahwa ibu Asma' yang bernama Qutailah berkunjung membawa hadiahhadiah buat putrinya itu (Asma') tetapi ia enggan menerimanya. Dia bertanya kepada saudaranya (Aisyah RA) dan kemudian turunlah ayat di atas. Nabi pun memerintahkannya untuk menyambut ibunya dan menerima hadiah-hadiah dari pemberiannya".

Ayat tersebut mengajarkan kepada untuk berbuat adil dan toleran kepada siapapun dan agama apapun. Hal ini merupakan perintah Allah yang juga memiliki batasan dan pokok syarat yang harus dipenuhi seperti tidak memerangi atau memusuhinya. Syayyid Qutub dalam menafsirkan ayat diatas menelaskan bahwa Islam adalah agama damai dan akidah cinta. Ia merupakan satu sistem yang bertujuan untuk menaungi seluruh alam dengan naungannya yang berupa kedamaian dan cinta tersebut.

Berangkat dari kisah fathu Makkah di masa rasulullah, saat itu kaum kafir Makkah merasa takut akan pembalasan oleh Rasulullah. Namun, ternyata Rosulullah justru memberikan pernyataan yang melindungi kaum dzimmi. Sebagaimana 
Rasulullah, khalifah Umar bin Khattab juga melakukan hal yang sama tatkala berhasil menaklukkan Persia dan merebut Palestina. Dalam sebuah hadis shahih, Rasul bersabda, "Aku wasiatkan (titipkan) atas ahl al-dzimmah ku, barangsiapa yang menyakiti ahl al-dzimmah maka ia benar-benar telah menyakitiku, barangsiapa yang menyakitiku maka ia telah menyakiti Allah".

Pada dasarnya, Islam adalah agama rahmatan lil 'alamin yang tidak mengajarkan untuk melakukan tindakan diskriminasi terhadap non-muslim. Justru sebaliknya, Islam mengajarkan perbuatan untuk saling menghormati terhadap sesama keturunan adam sebagaimana firman $\mathrm{Al}$ lah dalam surat Al-Isra' ayat 70.Ibnu Katsir menjelaskan dalam tafsirnya bahwa Allah telah melebihkan keutamaan bagi manusia lebih dari apapun yang diciptakan-Nya, lebih mulia dari seluruh makhluk hidup di dunia ini. Ayat ini juga menjelaskan keutamaan jasad manusia dibanding Malaikat.Dari beberapa pendapat mufassir dan riwayat di atas, tergambar jelas bagaimana sikap toleransi dan egalitarian Roasulullah dalam menghormati sesama manusia. selain itu, sikap kooperatif dan simpatik terhadap ahl al dzimmah juga telah ditunjukkan oleh beliau dalam wujud Piagam Madinah. Jadi, dapat disimpulkan bahwa kebebasan beragama dan beribadah menurut agama dan kepercayaannya telah mendapat legitimasi dari Alquran dan Hadis. Hal ini menunjukkan adanya kesempatan dan posisi yang sama dan sederajat dalam mendirikan tempat ibadah dan beraktifitas di dalamnya.

\section{FIQIH HAK ASASI MANUSIA DAN KESETARAAN HAK BERIBADAH WARGA NEGARA}

Berbicara tentang Fikih hak asasi manusia (HAM), kesan pertama yang dimunculkan adalah hubungannya dengan urusan ubudiyyah. Fikih berarti tuntunan atau cara untuk melakukan suatu ibadah. Pada masa modern saat ini, kita tidak hanya dihadapkan dengan permasalahanpermasalahan klasik terkait dengan ubudiyah saja. Kehidupan yang semakin kompleks membuat manusia berpikir lebih dinamis. Saat ini muncul berbagai pandangan terkait hal-hal yang sensitif dengan menambahkan kata fikih di depannya. Sebagai contoh fikih jurnalistik, fikih pendidikan, fikih wanita dan lain sebagainya.Fikih yang dimaksud dalam konteks ini berupaya untuk mengajak masyarakat untuk berpikir global dan berwawasan agama. Dunia internasional telah mengakui dan memperjuangkan pengakuan HAM melalui berbagai konferensi internasional. Banyak diantara masyarakat dunia menganggap bahwa HAM tidak sesuai dengan syariat Islam, bahkan dianggap sebagai produk kafir.

Tujuan diberikannya hak kepada warga nonmuslim dzimmi adalah untuk membina dan membangun komunitas kemasyarakatan yang kokoh. Hal ini sebagaimana dicontohkan oleh Rasulullah SAW yang didasarkan pada firman Allah surat An-Nisa' ayat 1 berikut,

"Hai sekalian manusia, bertakwalah kepada Tuhan-mu yang telah menciptakan kamu dari seorang diri, dan dari padanyaAllah menciptakan isterinya; dan dari pada keduanya Allah memperkembang biakkan laki-laki dan perempuan yang banyak. dan bertakwalah kepada Allah yang dengan (mempergunakan) nama-Nya kamu saling meminta satu sama laindan (peliharalah) hubungan silaturrahim. Sesungguhnya Allah selalu menjaga dan mengawasi kamu".

Dari segi ilmu Balaghah, ayat di atas bersifat kalam al khabar, mengandung misi informasi, hal ini berarti manusia diciptakan dari jenis laki-laki dan perempuan, bercorak suku berbeda bangsa. Namun memiliki harkat, derajat dan martabat yang sama di hadapan Allah SWT (Firdausi, 2013:7). Menurut Ali al-Shobuni dalam kitab Shafwatut Tafaasir, asbab an nuzul ayat ini menurut Ibnu al-Syakir berkenaan dengan keinginan Rasulullah untuk menikahkan Abi Hindun dengan seorang wanita dari kalangan Baidhah. Kemudian Bani Baidhah dengan sinis mengatakan "ya Rasulullah, pantaskah kami mengawinkan putri kami dengan budak kami?" belum sempat menjawab pertanyaan tersebut, turunlah Jibril membawa ayat tersebut. Dengan demikian, Islam memandang kesamaan derajat antar makhluk Allah, sesama manusia. Atas kesamaan derajat inilah, Islam sangat melarang menyakiti dan menomorduakan kaum ahl al-dzimmah.

Permasalahan yang sering muncul di Indonesia terkait dengan hal ini adalah permasalahan pendirian rumah ibadah. Mengapa hal itu terjadi?, Karena masyarakat masih berpikir bahwa komunitas di lingkungannya harus steril dan tetap berada digenggaman kekuasaan kelompoknya. 
Keberadaan peraturan bersama Menteri Agama dan Menteri Dalam Negeri Nomor 8 dan Nomor 9 tentang hal ini, diharapkan mampu meredam gejolak konflik di masyarakat. Namun faktanya berbeda, justru dengan adanya peraturan ini, masyarakat semakin menolak adanya pendirian rumah ibadah baru di lingkungannya. Oleh karena itu, saat ini peraturan menteri berkaitan dengan pendirian rumah ibadah ditinjau kembali (yudicial review) oleh Mahkamah Agung. Masyarakat menilai peraturan tersebut tidak sejalan dengan Undang-undang Nomor 1 Tahun 1999 tentang Hak Asasi Manusia dan juga tidak sejalan dengan konsitusi negara.

Sebagai ikhtiar dalam mengarusutamakan wacana fikih HAM, penulis mencoba untuk mengkonstruksi dasar pengambilan hukum dan justivikasi keagamaan terhadap hak asasi manusia dalam tabel 1.

Variaan atau model konstruksi di atas merupakan bagian universal yang juga diakui sebagai hak-hak dasar manusia dalam dunia internasional. Alquran sebagai sumber primer penggalian sumber hukum Islam juga memposisikan HAM dalam kerangka Maqasid Al-Syari'ah. Fikih HAM juga sejajar dengan fikih Maqasidiyang mencoba keluar dari klasikal tekstual menuju penyelesaian masalah kontemporer kehidupan saat ini. Konsep pengakuan HAM dalam Islam tercermin dari pemaknaan Alquran terhadap berbagai peristiwa sosial kemasyarakatan dan kemanusiaan yang terjadi. Alquran selalu merespon setiap kejadian yang kurang manusiawi dengan penguatan kalam ilahiyah. Pada dasarnya Islam dan Alquran sangat menghormati dan menghargai hak asasi manusia dalam konteks dan proporsi syariat Islam pada umumnya.

\section{SIMPULAN}

Fenomena penolakan pendirian rumah ibadah yang dialami oleh minoritas dzimmi di tengah mayoritas muslim sering terjadi.Ahl aldzimmahdianggap sebagai kaum nomor dua yang dapat diperlakukan seenaknya. Padahal konsepsi Al-Quran terhadap kesetaraan hak beribadah minoritas dzimmi juga telah diatur. Di sisi yang lain, pemerintah juga berupaya untuk menciptakan suasana kesetaraan hak melalui peraturan menteri, yang pada akhir-akhir ini juga digugat ke Mahkamah Agung untuk dibatalkan. Terlepas dari berbagai fenomena tersebut, pada hakikatnya hak beragama dan beribadah menurutkeyakinannya adalah hak asasi yang bersifat mutlak. Tak boleh ada seorang pun dan dalam kondisi apapun mengganggu terlaksananya hak tersebut. Yudicial review atas peraturan tersebut merupakan langkah yang nyata untuk menghadirkan suasana harmonis antarumat beragama.

Tulisan ini mencoba untuk membangun wawasan dinamis terhadap hak-hak minoritas dzimmi dalam mendirikan rumah ibadah di tengah mayoritas muslim Indonesia. Kajian fikih HAM yang juga sejalan dengan fikih Maqasidi diharapkan mampu mendewasakan pemikiran masyarakat Indonesia. Maqasid al-syariah sebagai

Tabel 1. Varian Konstruksi Fikih HAM Universal

\begin{tabular}{|c|c|c|}
\hline No. & Varian HAM & Dasar Pengambilan Hukum \\
\hline 1. & Hak untuk Hidup & $\begin{array}{l}\text { QS. Al-Maidah ayat } 32 ; \\
\text { QS. Al-An'am ayat } 151 ;\end{array}$ \\
\hline 2. & Hak Mendapatkan Keselamatan & QS. Al-Maidah ayat 32; \\
\hline 3. & Hak memperoleh Kebutuhan Pokok & QS. Ad-Dzariyat ayat 19; \\
\hline & Hak Kemerdekaan dan Kebebasan & QS. An-Nisa' ayat 93; \\
\hline & & $\begin{array}{l}\text { QS. Al-Baqarah ayat 188; } \\
\text { QS. Al-Hujurat ayar 12-13; }\end{array}$ \\
\hline 5. & Hak Beribadah, Berpendapat dan Berserikat & $\begin{array}{l}\text { QS. Al-An'am ayat } 180 ; \\
\text { QS. At-Taubah ayat } 67 ; \\
\text { QS. At-Taubah ayat } 71 ; \\
\text { QS. Al-Hajj ayat } 41 ; \\
\text { QS. Ali Imron ayat } 110 ;\end{array}$ \\
\hline
\end{tabular}


landasan fikih ini mencoba mendialogkan tekstual agama klasik dengan isu kontemporer dalam menyelesaikan masalah. Fikih HAM adalah

\section{DAFTAR RUJUKAN}

Firdausi, Nuri. 2013. Fikih Minoritas: Hak Asasi Dzimmi di Tengah Mayoritas

Muslim.Malang: Makalah Ilmiah Alquran al-Hakim, Suparlan. 2016. Pendidikan Kewarganegaraan dalam Konteks

Indonesia. Malang: Setara Perss.

Huwaydi, Fahmi. 1999. Muwathinun la Dzimmiyyatun. Cetakan ke-3. Kairo: Dae el-Shoruq.

Jonathan Z, Smith (ed). 1995. The Happercollins Dictionary of Religion.

New York: American Academy

Kementerian Agama Republik Indonesia. 2016. Al-Quran dan Terjemahannya.

Jakarta: Direktorat Bimas Islam Kementerian Agama Republik Indonesia

Ketetapan MPR RI Nomor III/MPR/2000 tentang Sumber Hukum dan Tata

Urutan Perundang-undangan sebagaimana telah ditinjau berdasarkan Ketetapan MPR RI nomor I/MPR/2003 tentang peninjauan kembali materi dan status hukum ketetapan MPRS dan ketetapan MPR RI tahun 1960 sampai dengan tahun 2002

Kumelo, Mujaid. 2015. Fiqh HAM: Ortodoksi dan Liberalisme Hak Asasi

Manusia dalam Islam. Malang: Setara Perss. Kementerian Agama Republik Indonesia. 2015. Kondisi kerukunan umat beragama di Indonesia. Jakarta: Dirpontren Kemenag. khazanah atau literasi baru keilmuan Islam kontemporer menuju harmoni kehidupan yang baldatun thoyyibatun wa rabbun ghafuur.

al-Maraghi, Mustofa. 1976. Tafsir Al-Quran AlKariim Al-Maraghi. Jakarta:

Pustaka Media

Peraturan Bersama Menteri Agama dan Menteri Dalam Negeri Nomor $8 \& 9$

Tahun 2006 tentang pedoman pelaksanaan tugas kepala daerah/wakil kepala daerah dalam pemeliharaan kerukunan umat beragama, pemberdayaan forum kerukunan umat beragama dan pendirian rumah ibadat.

Rodli, Ahmadi. 2013. Stigma Islam Radikal. Yogyakarta: Fakultas Tarbiyah dan

Keguruan UIN Sunan Kalijaga Yogyakarta.

Shihab, Quraish. 2002. Tafsir Al Misbah. Jakarta: Lentera Hati

-. 2013. Membumikan Al-Quran. Jakarta: Lentera Hati

Taufiqurrahman. 2013. Sang Nahkoda: Biografi Suryadarma Ali. Malang: UIN Press.

Undang-undang Dasar Negara Republik Indonesia Tahun 1945

Wiyono, Suko. 2015. Reaktualisasi Nilai-nilai Pancasila dalam Kehidupan

Berbangsa dan Bernegara. Malang: Wisnu Wardhana Press.

Yunus, Mahmud. 1989. Kamus Yusuf. Jakarta: Hidakarya Agung.

al-Zuhaili Wahba'. Fiqh Al Muwathinah. Kairo: Dar El Hikam 